\author{
Maša FILIPOVIĆ \\ Srna MANDIČ
}

\title{
Stanovanjska ranljivost v Mestni občini Ljubljana
}

Pojem ranljive skupine označuje družbene skupine, ki imajo v primerjavi z drugimi skupinami manj virov in so zato prikrajšane že $v$ izhodiščnem položaju. Eno od področij, na katerem je ranljivost lahko usodna za celotno življenje posameznikov in njihovih družin, je prav gotovo stanovanjsko področje. Na stanovanjsko ranljivost vplivajo tako institucionalni in strukturni, kot osebni in odnosni dejavniki ter je povezana z različnimi družbenimi skupinami. V članku analiziramo stanovanjske razmere ranljivih skupin v Mestni občini Ljubljana. Podrobneje je opisan njihov ekonomski položaj in njihove stanovanjske strategije, ki ponazarjajo kakšne možnosti imajo ranljive skupine za izboljšanje svojega stanovanjskega položaja in reševanje stanovanjskih težav. Pri tem se osredotočimo na naslednje ranljive skupine: enostarševske družine, družine z otroci, starejši in revni. Rezultati analize kažejo, da bi bili potrebni specifični inštrumenti podpore ranljivim skupinam tudi v lastniškem stanovanju, članek pa opozarja tudi na nevarnost razraščanja nekakovostnih in poceni najemnih stanovanj.

\section{Uvod}

Pojem ranljive skupine označuje družbene skupine, ki imajo $\mathrm{v}$ primerjavi z drugimi skupinami manj virov (na primer: denarja, informacij, stikov, raznovrstnih veščin itd.) in so zato slabše opremljene za tržno tekmo in v primerjavi z drugimi prikrajšane že v izhodiščnem položaju (več v: Mandič, 1999). Eno od področij, na katerem je ranljivost lahko usodna za celotno življenje posameznikov in njihovih družin, je prav gotovo stanovanjsko. Pri tem je skrb za ranljive skupine - tudi na stanovanjskem področju - poudarjena tako $\mathrm{v}$ mednarodnih dokumentih (na primer $v$ t. i. Lizbonski strategiji) kot tudi $\mathrm{v}$ slovenskih (npr. Nacionalni stanovanjski program) in dokumentih na lokal-
Vulnerable groups are defined as groups that have fewer resources than other population groups and are therefore in a deprivileged position from the beginning. One of important areas of vulnerability, which influences importantly individuals lives and lives of whole families, is the housing area. Institutional, structural, as well as personal and relational factors influence housing vulnerability. It is also something that touches very different population groups. In the article we analyse housing conditions of vulnerable groups in the Municipality of Ljubljana. We focus on the following vulnerable groups: single parent households, households with children, older people and low income groups. The economic situation of vulnerable groups is portrayed and their housing strategies for improving their housing situation are described. The results of the analysis indicate that specific support measures are needed for vulnerable households in homeownership status. The article also warns of the danger of development of wrack-renting, i.e. renting of low quality, low cost dwellings.

nih ravneh (kot je Stanovanjski program MOL za leto 2007).

$\mathrm{Na}$ stanovanjsko ranljivost vplivajo tako institucionalni in strukturni kot osebni in odnosni dejavniki (Edgar et al., 2002). Stanovanjska ranljivost lahko pomeni ranljivost $\mathrm{v}$ različnih domenah: v fizični (sama fizična prisotnost oz. odsotnost stanovanja in njegova kakovost), v legalni (na primer z zakonom zagotovljena pravica do uporabe) in tudi družbeni dimenziji (možnost zasebnosti, varnosti) (Edgar et al., 2004).

Stanovanjska ranljivost je povezana $z$ različnimi družbenimi skupinami. Pri nas je že več avtorjev opozarjalo na stanovanjsko problematiko posameznih ranljivih skupin
Stanovanjska ranljivost, Ranljive skupine, MOL

Housing vulnerability, Vulnerable groups, Municipality of Ljubljana 
(npr. Leskošek 1999, Zaviršek 1999, Flaker 1999, Mandič, idr. 2004, Dolenc 2003, Razpotnik in Dekleva 2005). Kot najbolj ranljive skupine se omenjajo predvsem družine z nizkim dohodkom, brezposelni, ljudje, odvisni od alkohola in mamil, slabo izobraženi, enostarševske družine, velike družine, etnične manjšine, ljudje s psihosocialnimi težavami in mladina, ki je ostala brez podpore staršev (Avramov, 1995; Duffy, 1998). Slovenija se glede na raziskave $v$ tem ne razlikuje dosti od Evrope in prej omenjenih skupin. Tako Boškič in Filipović (2002) na podlagi raziskave med organizacijami navajata kot najpogosteje opredeljene ranljive skupine na stanovanjskem področju: brezposelne oziroma družine $z$ brezposelnim članom, enoroditeljske družine, invalidi oziroma družine $\mathrm{Z}$ invalidnim članom, ljudje brez državljanstva, priseljenci, ljudje brez dovoljenja za stalno prebivanje v Sloveniji, pripadniki drugih etničnih skupin, mlade družine, posamezniki s težavami v duševnem zdravju, revni, samski, starejši (predvsem samski upokojenci), zaporniki po prestani kazni, ženske žrtve nasilja, žrtve zlorab, ženske z otroki po razpadu zakonske zveze in odvisniki.

Ranljive skupine so torej tiste skupine, ki imajo v primerjavi z drugim prebivalstvom slabši izhodiščni položaj za uspeh in ki lahko hitreje zaidejo v težave. Tako težko rešujejo svojo neprimerno stanovanjsko situacijo, saj je reševanje stanovanjskih težav pove- zano z veščinami, ki ljudem niso prirojene. Hkrati se lahko negativne izkušnje na stanovanjskem področju ranljivih skupin kopičijo, kar posledično lahko vodi v resignacijo in stanovanjsko izključenost. V članku analiziramo stanovanjske razmere ranljivih skupin v MOL. Podrobneje je opisan njihov ekonomski položaj in njihove stanovanjske strategije, ki ponazarjajo, kakšne možnosti imajo ranljive skupine za izboljšanje svojega stanovanjskega položaja in reševanje stanovanjskih težav. Pri tem se osredotočimo na naslednje ranljive skupine:

- enostarševske družine,

- družine z otroki,

- starejši in

- revni [1].

\section{Stanovanjske razmere in stanovanjski status ranljivih skupin v Ljubljani}

Najprej poglejmo, ali imajo ranljive skupine značilen vzorec nastanitve glede na tip stanovanjske enote in značilnosti stavb, kar prikazuje naslednja preglednica.

Glede na vrsto stanovanjske enote tako kot v celotnem prebivalstvu tudi med vsemi ranlji-

Preglednica 1: Ranljive skupine prebivalstva po vrsti stanovanja, tipu stavbe, velikosti stavbe in obdobju izgradnje stavbe

\begin{tabular}{|c|c|c|c|c|c|}
\hline & $\begin{array}{c}\text { Enostarševska } \\
\text { gospodinjstva } \\
(\mathrm{n}=45) \\
(\%)\end{array}$ & $\begin{array}{l}\text { Družine } z \text { otroki } \\
\text { do } 18 \text { let } \\
(n=147) \\
(\%)\end{array}$ & $\begin{array}{c}\text { Stari } 65 \text { in } \\
\text { več let } \\
(n=124) \\
(\%)\end{array}$ & $\begin{array}{c}\text { Revni } \\
(\%)\end{array}$ & $\begin{array}{c}\text { Vsi } \\
\text { Ljubljančani } \\
(n=648) \\
(\%)\end{array}$ \\
\hline \multicolumn{6}{|l|}{ Vrsta stanovanja } \\
\hline - družinska hiša & 13,0 & 23,8 & 25,8 & 13,2 & 20,6 \\
\hline - stanovanje & 87,0 & 75,5 & 65,3 & 82,1 & 72,5 \\
\hline - garsonjera & 0,0 & 0,0 & 6,5 & 4,7 & 6,3 \\
\hline - drugo & 0,0 & 0,7 & 2,4 & 0,0 & 0,6 \\
\hline Skupaj & 100,0 & 100,0 & 100,0 & 100,0 & 100,0 \\
\hline \multicolumn{6}{|c|}{ Stavbe po obdobju izgradnje } \\
\hline - do leta 1914 & 19,0 & 8,1 & 7,8 & 12,9 & 8,3 \\
\hline - 1914 do 1949 & 0,0 & 13,2 & 13,8 & 6,5 & 9,9 \\
\hline - 1950 do 1969 & 31,0 & 30,9 & 37,9 & 34,4 & 30,7 \\
\hline-1970 do 1990 & 42,9 & 36,0 & 38,8 & 44,1 & 45,9 \\
\hline - 1991 ali kasneje & 7,1 & 11,8 & 1,7 & 2,2 & 5,3 \\
\hline Skupaj & 100,0 & 100,0 & 100,0 & 100,0 & 100,0 \\
\hline
\end{tabular}

Vir: Stanovanjska anketa 2005, Univerza v Ljubljani, IDV FDV, CDB 
vimi skupinami prevladujejo stanovanja, vendar pa je ta prevlada najbolj izrazita pri enostarševskih družinah in med revnimi gospodinjstvi. Vsekakor pa prevlada stanovanj ni tako izrazita, da bi lahko zanemarili tiste, ki žive v družinskih hišah. To je zlasti pomembno za družine $z$ otroki in starejše ljudi, med katerimi jih tako prebiva približno četrtina.

Glede starosti stavb in stanovanj pa se med ranljivimi kaže izrazita razlika. Enostarševska gospodinjstva in revni prebivajo pogosteje od drugih $v$ najstarejših stanovanjih (zgrajenih pred letom 1914) ter v tistih, zgrajenih v zadnjih dveh desetletjih socializma, ki se tako kaže kot dokaj darežljiv za ti dve skupini. Drugače kot ti dve skupini pa družine $z$ otroki in starejši kažejo večjo prisotnost od drugih v stanovanjih, zgrajenih med vojnama, družine $\mathrm{z}$ otroki pa tudi v najnovejših stanovanjih.

Poglejmo še, v kako velikih stanovanjih bivajo ranljive skupine (preglednica 2).

Glede na velikost stanovanja $\mathrm{v} \mathrm{m}^{2}$ se pokaže, da živijo enostarševska gospodinjstva in revni $v$ znatno manjših stanovanjih (mediana $49 \mathrm{~m}^{2}$ in $48 \mathrm{~m}^{2}$ ) kot celotna populacija, družine $\mathrm{z}$ otroki pa $\mathrm{v}$ večjih (mediana $64 \mathrm{~m}^{2}$ ). Po številu sob izstopajo le družine $z$ otroki, pri katerih je mediana 3 sobe. Dejstvo, da gre pri teh skupinah tudi za različno velika gospodinjstva, se pokaže v nadaljevanju, kjer obravnavamo stanovanjske razmere konkretnih gospodinjstev, med njimi tudi vprašanje prenaseljenosti.

V naslednji preglednici (3) so podatki o tem, kako pogosto ranljive skupine in celotno prebivalstvo Ljubljane zaznavajo izbrane težave.
Med težavami v zvezi s fizičnimi značilnostmi stanovanja vidno izstopajo enostarševska gospodinjstva, ki imajo izrazito več vseh težav kot drugi: pomanjkanje prostora in svetlobe, vlago, pomanjkljive napeljave. Med drugimi ranljivimi je teh težav praviloma manj, vendar pa je skupina revnih zelo blizu tej najbolj prikrajšani skupini. Družine z otroki imajo manj težav kot drugi, le pri pomanjkanju prostora so zelo visoko, saj jih ima to težavo več kot polovica. Ta težava pesti tudi 40 \% starejšega prebivalstva, kar opozarja, da kljub v povprečju relativno velikim stanovanjskim površinam starejših obstaja med njimi znatna skupina, ki ima pomanjkanje prostora.

Glede kazalcev o varnosti in svobodi pri uporabi stanovanja se ponovno kot najbolj prizadeta pokaže skupina enostarševskih gospodinjstev, ki izraža negotovost glede stanovanja in pomanjkanje zasebnosti bistveno pogosteje od drugih, pri čemer pa skupina revnih le malo zaostaja za njimi. Premalo zasebnosti pa je pomembno prisotna težava tudi v skupini družin $z$ otroki, kar poleg dokaj izražene težave "preveč omejitev « opozarja na nezadovoljene specifične potrebe večgeneracijskih gospodinjstev.

Glede stanovanjskega okolja lahko vidimo, da imajo enostarševska gospodinjstva pogosteje od drugih težave s parkiranjem, nedostopnimi rekreacijskimi površinami, $\mathrm{z}$ onesnaženim zrakom in hrupom ter s pomanjkanjem primernega prostora za igro otrok, zelo blizu teh rezultatov pa so tudi revna gospodinjstva.

V preglednici 4 poglejmo še druge kazalce stanovanjskih razmer. Kar zadeva relativno po-

Preglednica 2: Ranljive skupine prebivalstva po velikosti stanovanja

\begin{tabular}{|c|c|c|c|c|c|}
\hline & $\begin{array}{l}\text { Enostarševska } \\
\text { gospodinjstva }\end{array}$ & $\begin{array}{c}\text { Družine } z \text { otroki } \\
\text { do } 18 \text { let }\end{array}$ & $\begin{array}{l}\text { Stari } 65 \text { in } \\
\text { več let }\end{array}$ & Revni & $\begin{array}{c}\text { Vsi } \\
\text { Ljubljančani }\end{array}$ \\
\hline \multicolumn{6}{|l|}{ Velikost v $\mathrm{m}^{2}$} \\
\hline - povprečje & 59,84 & 71,57 & 61,10 & 50,00 & 62,33 \\
\hline$-S D$ & 32,188 & 33,664 & 27,680 & 19,551 & 31,190 \\
\hline - mediana & 49,00 & 64,00 & 58,00 & 48,00 & 58,00 \\
\hline \multicolumn{6}{|l|}{ Število sob } \\
\hline - povprečje & 2,23 & 2,93 & 2,37 & 1,96 & 2,33 \\
\hline$-S D$ & 1,351 & 1,378 & 1,259 & 1,085 & 1,323 \\
\hline - mediana & 2,00 & 3,00 & 2,00 & 2,00 & 2,00 \\
\hline
\end{tabular}

Vir: Stanovanjska anketa 2005, Univerza v Ljubljani, IDV FDV, CDB 
Preglednica 3: Pogostnost navedenih težav* med ranljivimi skupinami

\begin{tabular}{|c|c|c|c|c|c|}
\hline & $\begin{array}{c}\text { Enostarševska } \\
\text { gospodinjstva } \\
(\%)\end{array}$ & $\begin{array}{l}\text { Družine } z \text { otroki } \\
\text { do } 18 \text { let } \\
(\%)\end{array}$ & $\begin{array}{l}\text { Stari } 65 \text { in } \\
\text { več let } \\
\text { (\%) }\end{array}$ & $\begin{array}{c}\text { Revni } \\
(\%)\end{array}$ & $\begin{array}{c}\text { Vsi } \\
\text { Ljubljančani } \\
(\%)\end{array}$ \\
\hline \multicolumn{6}{|l|}{ Fizične značilnosti stanovanjske enote } \\
\hline - premalo prostora & 55,6 & 53,1 & 40,6 & 48,6 & 35,2 \\
\hline - vlaga & 19,6 & 9,5 & 6,5 & 15,9 & 11,2 \\
\hline - premalo svetlobe & 19,6 & 12,8 & 8,9 & 23,4 & 15,7 \\
\hline - pomanjkljive napeljave & 32,6 & 24,5 & 13,0 & 29,9 & 26,2 \\
\hline \multicolumn{6}{|l|}{ Varnost, svoboda } \\
\hline - negotovost glede stanovanja & 19,6 & 10,2 & 4,1 & 12,1 & 11,0 \\
\hline - premalo zasebnosti & 40,0 & 21,6 & 4,0 & 26,2 & 14,2 \\
\hline - preveč omejitev & 8,7 & 15,0 & 2,4 & 9,3 & 8,8 \\
\hline \multicolumn{6}{|l|}{ Stanovanjsko okolje } \\
\hline - težave s parkiranjem & 42,2 & 38,8 & 9,2 & 34,9 & 36,3 \\
\hline - slabe prometne povezave & 6,5 & 15,0 & 4,9 & 8,4 & 8,2 \\
\hline - ni rekreacijskih površin & 52,2 & 35,4 & 25,0 & 35,6 & 34,8 \\
\hline - onesnažen zrak & 61,4 & 52,1 & 44,7 & 56,2 & 53,2 \\
\hline- hrup & 46,7 & 42,2 & 35,5 & 49,5 & 42,3 \\
\hline - ni varnega prostora za igro otrok & 48,9 & 43,8 & 20,8 & 41,1 & 38,0 \\
\hline
\end{tabular}

* Ocena anketiranca, da je težava zanj zelo huda, huda ali niti-niti.

Vir: Stanovanjska anketa 2005, Univerza v Ljubljani, IDV FDV, CDB

Preglednica 4: Gospodinjstva ranljivih skupin po izbranih splošnih kazalcih stanovanjskih razmer

\begin{tabular}{|l|r|r|r|r|r|}
\hline & $\begin{array}{c}\text { Enostarševska } \\
\text { gospodinjstva }\end{array}$ & $\begin{array}{c}\text { Družine z otroki } \\
\text { do 18 let }\end{array}$ & $\begin{array}{c}\text { Stari } 65 \text { in } \\
\text { več let }\end{array}$ & Revni & $\begin{array}{c}\text { Vsi } \\
\text { Ljubljančani }\end{array}$ \\
\hline $\begin{array}{l}\text { Gospodinjstva, ki imajo neprimerne } \\
\text { stanovanjske razmere* }\end{array}$ & $47,8 \%$ & $37,9 \%$ & $21,7 \%$ & $50,9 \%$ & $34,2 \%$ \\
\hline $\begin{array}{l}\text { Gospodinjstva z manj kot sobo na člana } \\
\text { gospodinjstva }\end{array}$ & $46,7 \%$ & $66,0 \%$ & $8,9 \%$ & $57,0 \%$ & $38,7 \%$ \\
\hline Površina v m na osebo & & & & & \\
\hline - povprečje & 25,8317 & 19,5425 & 46,0620 & 24,0210 & 32,1761 \\
\hline - SD & 14,30139 & 10,19496 & 18,87738 & 13,30424 & 18,68755 \\
\hline - mediana & 20,2960 & 18,0388 & 40,0000 & 19,6364 & 27,000 \\
\hline Število sob na osebo & & & & & \\
\hline - povprečje & 0,9539 & 0,7921 & 1,7640 & 0,8900 & 1,1484 \\
\hline - SD & 0,59468 & 0,42105 & 0,91230 & 0,62698 & 0,77523 \\
\hline - mediana & 1,0000 & 1,2532 & 2,0000 & 0,7500 & 1,000 \\
\hline
\end{tabular}

* Neprimerne stanovanjske razmere so definirane kot: gospodinjstvo biva v stanovanju, ki ima vsaj eno od osnovnih pomanjkljivosti, t. j. $\mathrm{n}$ stranišča na izpiranje, huda ali zelo huda pomanjkljivost inštalacij, huda ali zelo huda vlaga, hudo ali zelo hudo pomanjkanje dnevne svetlobe ali/in primanjkuje prostor.

Vir: Stanovanjska anketa 2005, Univerza v Ljubljani, IDV FDV, CDB

Preglednica 5: Nezadovoljstvo s sedanjim stanovanjem med ranljivimi skupinami

\begin{tabular}{|l|c|c|c|c|c|}
\hline \multicolumn{1}{|c|}{ Zadovoljstvo s stanovanjem } & $\begin{array}{c}\text { Enostarševska } \\
\text { gospodinjstva } \\
(\%)\end{array}$ & $\begin{array}{c}\text { Družine z otroki } \\
\text { do 18 let } \\
(\%)\end{array}$ & $\begin{array}{c}\text { Stari 65 in } \\
\text { več let } \\
(\%)\end{array}$ & $\begin{array}{c}\text { Revni } \\
\text { (\%) }\end{array}$ & $\begin{array}{c}\text { Vsi } \\
\text { Ljubljančani } \\
(\%)\end{array}$ \\
\hline nezadovoljen & 56,5 & 43,2 & 21,0 & 48,6 & 36,5 \\
\hline zadovoljen & 43,5 & 56,8 & 79,0 & 51,4 & 63,5 \\
\hline Skupaj & 100 & 100 & 100 & 100 & 100 \\
\hline
\end{tabular}

Vir: Stanovanjska anketa 2005, Univerza v Ljubljani, IDV FDV, CDB 
vršino stanovanja, torej $\mathrm{m}^{2}$ na osebo, imajo vse ranljive skupine (razen starejših) znatno nižjo vrednost kot Ljubljančani nasploh; starejši $\mathrm{z}$ mediansko vrednostjo $40 \mathrm{~m}^{2}$ na osebo za dvakrat prekašajo mediansko površino na osebo drugih ranljivih skupin. Podobna razmerja so tudi glede števila sob na osebo, kjer pa zelo izstopa nizka medianska vrednost revnih gospodinjstev - 0,75 sobe na osebo. Če kot mero prenaseljenosti uporabimo v EU splošno sprejet prag soba na osebo, dobimo oceno odstotka gospodinjstev v prenaseljenem stanovanju. Med starejšimi je takih blizu 10 \% gospodinjstev, med vsemi drugimi ranljivimi skupinami pa izrazito več; med revnimi in enostarševskimi gospodinjstvi celo blizu polovice. Med družinami z otroki je takih kar 66 \%, vendar pa je to sliko potrebno relativizirati, kolikor zadeva majhne otroke.

In nazadnje še sintetičen kazalec stanovanjskih razmer, ki upošteva več dimenzij (od osnovnih pomanjkljivosti, do vlage, pomanjkanja prostora in svetlobe). Ta nam pokaže, da med revnimi in enostarševskimi gospodinjstvi nima primernih stanovanjskih razmer približno polovica gospodinjstev. Med družinami z otroki je takih v neprimernih stanovanjskih razmerah sicer manj, a še vedno blizu $40 \%$, med starejšimi malo več kot $20 \%$

Podatki o izstopajoči stanovanjski prikrajšanosti med enostarševskimi gospodinjstvi ter nekaj manj med revnimi se potrjujejo tudi $\mathrm{v}$ subjektivnih ocenah anketirancev o zadovoljstvu s stanovanjem. Kot kaže preglednica 5, je med enostarševskimi gospodinjstvi s stanovanjem nezadovoljnih več kot polovica gospodinjstev, malo manj med revnimi, med družinami z otroki blizu $40 \%$, med starejšimi pa najmanj, okoli 20 \%, kar je tudi manj od ljubljanskega povprečja.
Za vprašanje dostopnosti stanovanj je bistvenega pomena način pridobitve stanovanja. Videli smo, da je v Ljubljani relativno malo najemnih stanovanj nasploh, tudi socialnih/neprofitnih, prav ta pa so pomembna za ranljive skupine. Kot kaže preglednica 6, izstopajo naslednje značilnosti posameznih skupin. Med vsemi skupinami prevladuje lastniški status. To nakazuje na veliko potrebo po specifičnih inštrumentih podpore ranljivim skupinam tudi v lastniškem stanovanju. To še posebej velja za starejše, ki so v lastniškem stanovanju še pogosteje od drugih.

Za enostarševska gospodinjstva je značilno, da znatno pogosteje od drugih živijo v neprofitnih stanovanjih, kar potrjuje njihovo socialno funkcijo v mestu. Veliko jih je tudi $\mathrm{v}$ tržnih najemnih stanovanjih. Za revna gospodinjstva je značilno, da bistveno redkeje od drugih prebivajo v cenovno ugodnejših opcijah (neprofitno stanovanje in kot uporabnik, ki ne plačuje najemnine), veliko pogosteje od drugih pa v tržnih stanovanjih. To opozarja na nevarnost razraščanja nekakovostnih in poceni najemnih stanovanj; seveda to kaže tudi na velik primanjkljaj neprofitnih oz. socialnih stanovanj. Za družine $\mathrm{Z}$ otroki je značilno, da relativno pogosto bivajo v neprofitnem stanovanju, redkeje od drugih $\mathrm{v}$ tržnem, izrazito in značilno pogosteje pa kot uporabnik, ki ne plačuje najemnine in torej najverjetneje živi v stanovanju, ki je $\mathrm{v}$ lasti sorodnikov.

Ob koncu obravnave stanovanjskih razmer ranljivih skupin $\mathrm{v}$ Ljubljani še poglejmo, kako so locirane v prostoru mesta Ljubljane. Zanima nas, ali se kažejo kakšni značilni poselitveni vzorci. Kot kaže naslednja preglednica 7 , je opazno, da enostarševska gospodinjstva in revni v središču mesta bivajo pogosteje od ostalih prebivalcev Ljubljane, in

Preglednica 6: Ranljive skupine po stanovanjskem statusu

\begin{tabular}{|l|c|c|c|c|}
\hline & $\begin{array}{c}\text { Enostarševska } \\
\text { gospodinjstva } \\
(\%)\end{array}$ & $\begin{array}{c}\text { Družine z otroki } \\
\text { do 18 let } \\
(\%)\end{array}$ & $\begin{array}{c}\text { Stari 65 in } \\
\text { več let } \\
(\%)\end{array}$ & $\begin{array}{c}\text { Vsi } \\
\text { Levni } \\
(\%)\end{array}$ \\
\hline Lastnik, solastnik & 73,3 & 77,7 & 87,0 & 70,8 \\
\hline Najemnik neprofitnega stanovanja & 13,3 & 6,1 & 4,1 & 7,3 \\
\hline Najemnik tržnega/službenega stanovanja & 11,1 & 4,7 & 4,1 & 13,2 \\
\hline Uporabnik, ki ne plačuje najemnine & 2,2 & 10,8 & 4,1 & 3,8 \\
\hline Drugo & 0,0 & 0,7 & 0,8 & 0,9 \\
\hline Skupaj & 100,0 & 100,0 & 100,0 & 10,0 \\
\hline
\end{tabular}

Vir: Stanovanjska anketa 2005, Univerza v Ljubljani, IDV FDV, CDB. 
Preglednica 7: Gospodinjstva ranljivih skupin po lokaciji v mestu

\begin{tabular}{|l|c|c|c|c|c|}
\hline & $\begin{array}{c}\text { Enostarševska } \\
\text { gospodinjstva } \\
(\%)\end{array}$ & $\begin{array}{c}\text { Družine z otroki } \\
\text { do 18 let } \\
(\%)\end{array}$ & $\begin{array}{c}\text { Stari 65 in } \\
\text { več let } \\
(\%)\end{array}$ & $\begin{array}{c}\text { Revni } \\
(\%)\end{array}$ & $\begin{array}{c}\text { Vsi } \\
\text { Ljubljančani } \\
\text { (\%) }\end{array}$ \\
\hline V središču mesta & 40,0 & 27,0 & 17,8 & 32,7 & 27,9 \\
\hline Druga mestna četrt & 28,9 & 39,4 & 33,9 & 29,6 & 40,4 \\
\hline Obrobje & 31,1 & 33,6 & 48,3 & 37,8 & 31,7 \\
\hline Skupaj & 100,0 & 100,0 & 100,0 & 100,0 & 100,0 \\
\hline
\end{tabular}

Vir: Stanovanjska anketa 2005, Univerza v Ljubljani, IDV FDV, CDB.

sicer je prvih kar $40 \%$. Starejši so pogosteje od ostalih skupin locirani na obrobju. V druge mestne četrti se prav vse ranljive skupine naseljujejo redkeje kot splošno prebivalstvo Ljubljane. To opozarja na koncentracijo najbolj ranljivih skupin $\mathrm{v}$ mestnem središču, kar hkrati nakazuje koncentracijo stanovanj slabše kakovosti na tem območju in torej posledično degradacijo središča mesta.

\section{Ekonomski položaj ranljivih skupin}

Najbolj običajno razumevanje ranljivih in marginaliziranih skupin slednjim pripisuje predvsem slabši ekonomski status. V nadaljevanju so prikazani podatki, ki kažejo ekonomski položaj ranljivih skupin.

Povprečni dohodki so pri vseh obravnavanih ranljivih skupinah nižji od povprečja v Ljubljani. Nižji dohodek potrjuje tudi mediana. Pri tem kot najbolj ranljiva izstopajo enostarševska gospodinjstva in pa revni.

Za ranljivost je morda še bolj kot dohodek pomembno shajanje z njim, t. j. ali lahko gospodinjstva kaj prihranijo, ali lahko brez težav plačujejo stanovanjske stroške in posojila.
Podatki kažejo, da velik del ranljivih gospodinjstev zelo malo prihrani, z izjemo gospodinjstev z otroki do 18 let, kjer je delež takih, ki nekaj prihranijo, višji, kot velja v povprečju za Ljubljano. Enostarševske družine in revni pa izstopajo z zelo visokim deležem anketirancev (dve tretjini), ki ničesar ne prihranijo. Hkrati sta to tudi skupini, v katerih je nadreprezentiran delež anketirancev, ki so menili, da obstaja velika nevarnost izgube dohodka.

Velik delež gospodinjstev, ki ne prihrani ničesar, kaže na visoko obremenjenost dohodkov. $\mathrm{V}$ anketi smo analizirali obremenjenost dohodkov s posojili in s stanovanjskimi stroški. Stanovanjski stroški predstavljajo največji delež v dohodkih starejših gospodinjstev, revnih in enostarševskih družin. Med njimi namreč več kot tretjina anketiranim stanovanjski stroški predstavljajo več kot 30 \% dohodkov. V ZDA uvrščajo v merila primernega stanovanja varnost, ustreznost in cenovno dosegljivost v smislu, da gospodinjstvo za stanovanje ne plača več kot 30 \% letnega dohodka (US departement of housing and urban development; v Mandič in Filipovič, 2005). Za vsa ta gospodinjstva bi torej lahko rekli, da živijo v neprimernem stanovanju. Še posebej so pri tem izpostavljeni revni, saj med njimi skoraj dvema tretjinama gospodinjstev stanovanjski stroški predstavljajo več kot 30 \% dohodkov.

Preglednica 8: Ekvivalentni dohodek ranljivih skupin v Ljubljani

\begin{tabular}{|l|c|c|c|c|c|}
\hline \multicolumn{1}{|c|}{ Dohodek } & $\begin{array}{c}\mathbf{6 5} \text { in več let } \\
(\mathbf{n = 1 2 4 )}\end{array}$ & $\begin{array}{c}\text { Enostarševsko } \\
\text { gospodinjstvo } \\
(\mathbf{n = 4 5 )}\end{array}$ & $\begin{array}{c}\text { Gospodinjstvo z } \\
\text { otroki (do 18 let) } \\
(\mathbf{n}=\mathbf{1 4 7})\end{array}$ & $\begin{array}{c}\text { Revni } \\
(\mathbf{n}=\mathbf{1 0 4})\end{array}$ & $\begin{array}{c}\text { Vsi Ljubljančani } \\
(\mathbf{n}=\mathbf{6 5 0})\end{array}$ \\
\hline povprečje & 145.652 & 136.464 & 174.560 & 67.752 & 179.058 \\
\hline standardni odklon & 69.657 & 91.197 & 82.297 & 20.081 & 91.403 \\
\hline mediana & 125.000 & 87.500 & 152.777 & 69.444 & 163.043 \\
\hline minimum & 33.333 & 33.333 & 23.810 & 16.667 & 16.667 \\
\hline maksimum & 450.000 & 566.667 & 472.222 & 97.826 & 566.667 \\
\hline
\end{tabular}

Vir: Stanovanjska anketa 2005, FDV IDV, CDB 
Z izjemo starejših gospodinjstev je dobra tretjina ranljivih gospodinjstev obremenjena tudi z odplačevanjem posojila. Nekoliko nižji delež je med revnimi, kjer je s posojilom obremenjena petina gospodinjstev. Med enostarševskimi družinami in družinami z otroki (do 18 let) je ta delež nekoliko višji, kot je povprečje v Ljubljani. Pri tem so s stanovanjskimi posojili $\mathrm{v}$ nekoliko večji meri obremenjene enostarševske družine in družine $\mathrm{z}$ otroki (do 18 let) kot druge ranljive skupine. Posojilo predstavlja kar desetini enostarševskih družin več kot 30 \% dohodka. Tudi med družinami z otroki (do 18 let) je delež takih, katerim posojilo predstavlja več kot $30 \%$ dohodka nadreprezentirano glede na Ljubljano.

\section{Pretekle in prihodnje stanovanjske strategije}

Stanovanjske strategije gospodinjstev nam omogočijo vpogled v njihove vire, s katerimi izboljšujejo svoj stanovanjski položaj. Pri tem nas v tem poglavju specifično zanimajo strategije ranljivih skupin. S tem želimo ugotoviti, kje obstaja primanjkljaj virov in kateri viri so najbolj obremenjeni. Na podlagi tega se lahko sklepa o potrebnih politikah za pomoč tem skupinam, kje je možen dodaten izkoristek virov ali pa potrebno povečanje opcij za najbolj ranljive skupine. Zato najprej analiziramo pretekle stanovanjske strategije.

Preglednica 9: Dohodkovno stanje ranljivih skupin v Ljubljani

\begin{tabular}{|c|c|c|c|c|c|}
\hline & $\begin{array}{c}65 \text { in več let } \\
(n=121) \\
(\%)\end{array}$ & $\begin{array}{c}\text { Enostarševsko } \\
\text { gospodinjstvo } \\
(\mathrm{n}=45) \\
(\%)\end{array}$ & $\begin{array}{l}\text { Gospodinjstvo z } \\
\text { otroki (do } 18 \text { let) } \\
\text { ( }=147) \\
(\%)\end{array}$ & $\begin{array}{c}\text { Revni } \\
(\mathrm{n}=104) \\
(\%)\end{array}$ & $\begin{array}{l}\text { Vsi Ljubljančani } \\
\begin{array}{c}(\mathrm{n}=628) \\
(\%)\end{array}\end{array}$ \\
\hline \multicolumn{6}{|l|}{ Ali v enem letu kaj prihranite? } \\
\hline - ničesar & 47,5 & 79,5 & 35,1 & 65,1 & 43,8 \\
\hline - nekaj prihrani & 52,5 & 20,5 & 64,9 & 34,9 & 56,2 \\
\hline Skupaj & 100,0 & 100,0 & 100,0 & 100,0 & 100,0 \\
\hline $\begin{array}{l}\text { Obstaja velika nevarnost izgube } \\
\text { dohodka* }^{*}\end{array}$ & 9,2 & 19,6 & 11,8 & 16,9 & 14,7 \\
\hline \multicolumn{6}{|l|}{ Delež stan. stroškov v dohodku } \\
\hline - do $10 \%$ & 13,9 & 21,6 & 38,8 & 5,8 & 31,7 \\
\hline$-\operatorname{nad} 10 \%$ do $30 \%$ & 54,7 & 37,8 & 48,8 & 31,7 & 51,0 \\
\hline$-\operatorname{nad} 30 \%$ & 31,4 & 40,5 & 12,5 & 62,5 & 17,3 \\
\hline Skupaj & 100,0 & 100,0 & 100,0 & 100,0 & 100,0 \\
\hline \multicolumn{6}{|l|}{ Posojilo } \\
\hline - odplačuje stanovanjsko posojilo & 4,1 & 13,3 & 14,2 & 7,5 & 9,7 \\
\hline - odplačujejo drugo posojilo & 4,1 & 22,2 & 21,6 & 13,2 & 16,3 \\
\hline - ne odplačuje posojila & 91,9 & 64,4 & 64,2 & 79,3 & 74,1 \\
\hline Skupaj & 100,0 & 100,0 & 100,0 & 100,0 & 100,0 \\
\hline \multicolumn{6}{|l|}{ Delež posojila v dohodku } \\
\hline - do $10 \%$ & & 2,2 & 3,5 & 0,9 & 4,2 \\
\hline$-\operatorname{nad} 10 \%$ do $30 \%$ & 4,1 & 22,2 & 23,8 & 15,1 & 14,2 \\
\hline$-\operatorname{nad} 30 \%$ & 2,5 & 11,1 & 6,3 & 4,7 & 5,2 \\
\hline - nima posojila & 93,4 & 64,4 & 64,4 & 79,2 & 76,4 \\
\hline Skupaj & 100,0 & 100,0 & 100,0 & 100,0 & 100,0 \\
\hline
\end{tabular}

* Deleži predstavljajo odstotek anketirancev, ki so odgovorili na vprašanje: "Ocenite, kolikšna je nevarnost, da bi redne dohodke ali velik del izgubili? « (Ocene: od 1 do 5; 1 pomeni zelo majhna nevarnost izgube, 5 - zelo velika nevarnost izgube) odgovorili 4 ali 5.

(()) Pomeni, da so deleži ilustrativni zaradi majhnega $n$ (manjši kot 40 enot).

Vir: Stanovanjska anketa 2005, FDV IDV, CDB 
Predstavili smo že, da ima največji delež vseh gospodinjstev, tudi ranljivih, lastniški status. Velika večina je do tega statusa prišla Z nakupom stanovanja. Nadgradnja in prenova stanovanj sta najredkeje uporabljeni strategiji, tako v Ljubljani na splošno kot med ranljivimi skupinami. Nova gradnja pa je nekoliko pogostejša med starejšimi gospodinjstvi (v primerjavi z ljubljanskim povprečjem). Ranljive skupine so tudi nekoliko redkeje prejele svoje obstoječe stanovanje kot darilo ali z dedovanjem. To ni presenetljivo, saj je ta strategija bolj možna med premožnejšimi. Zanimivo je, da so ranljive skupine redkeje $\mathrm{v}$ stanovanju sorodnikov kot to velja v povprečju za Ljubljano, z izjemo družin z otroki (do 18 let). Za starejša gospodinjstva to ne preseneča, saj so običajno v fazi življenjskega cikla, ko so že pridobila svoje stanovanje. Vendar pa nižji delež takih med revnimi in enostarševskimi družinami lahko nakazuje na manjšo dosegljivost tega vira pomoči, t. j. pomoči sorodnikov, ki bi ponudili stanovanje za bivanje.
Lastna sredstva prevladujejo kot vir za pridobitev stanovanja pri vseh opazovanih skupinah ter v ljubljanski populaciji na splošno. Velika večina starejših gospodinjstev (71 \%) jih je uporabila. Tudi pri drugih ranljivih skupinah so ti deleži nad ljubljanskim povprečjem. Izjema so revni, ki so skupina, ki je v najmanjšem deležu uporabila lastna sredstva, kar kaže na to, da je slednjih verjetno imela najmanj.

Poleg tega je bila precej pogost vir tudi finančna pomoč sorodnikov. Nekoliko višji delež kot v Ljubljani je v treh skupinah: revni, enostarševske družine in gospodinjstva $Z$ otroki, pri čemer je največji delež takih, ki so dobili finančno pomoč sorodnikov med družinami z otroki (do 18 let). Pomoč sorodnikov z zemljiščem ali objektom je v Ljubljani precej redka in enako velja med ranljivimi skupinami. Nekoliko pogostejša je pri družinah z otroki (do 18 let).

Posojila so zelo pogosta, saj je velik delež anketirancev slednja potreboval za nakup stano-

Preglednica 10: Pretekle stanovanjske strategije ranljivih skupin v Ljubljani

\begin{tabular}{|c|c|c|c|c|c|}
\hline & $\begin{array}{c}65 \text { in več let } \\
(\mathrm{n}=124) \\
(\%)\end{array}$ & $\begin{array}{c}\text { Enostarševsko } \\
\text { gospodinjstvo } \\
(\mathrm{n}=45) \\
(\%)\end{array}$ & $\begin{array}{c}\text { Gospodinjstvo z } \\
\text { otroki (do } 18 \text { let) } \\
\begin{array}{c}(n=147) \\
(\%)\end{array}\end{array}$ & $\begin{array}{c}\text { Revni } \\
(\mathrm{n}=107) \\
(\%)\end{array}$ & $\begin{array}{l}\text { Vsi Ljubljančani } \\
\begin{array}{c}(\mathrm{n}=650) \\
(\%)\end{array}\end{array}$ \\
\hline \multicolumn{6}{|l|}{ Sedanji status in način dosega le-tega } \\
\hline - lastnik z nakupom & 62,3 & 64,4 & 57,8 & 55,3 & 55,9 \\
\hline - lastnik z dedovanjem, darilo & 13,1 & 4,4 & 12,9 & 10,7 & 14,0 \\
\hline - lastnik z novogradnjo & 9,8 & 4,4 & 4,1 & 3,9 & 6,1 \\
\hline - lastnik z nadgradnjo & 0,8 & & 0,7 & & 0,5 \\
\hline - lastnik s prenovo & 0,8 & & 2,0 & & 1,3 \\
\hline - najemnik v neprofitnem & 4,1 & 13,3 & 6,1 & 11,7 & 3,9 \\
\hline - najemnik v profitnem/službenem & 4,1 & 11,1 & 4,8 & 13,6 & 11,0 \\
\hline - v stanovanju sorodnikov & 4,1 & 2,2 & 10,9 & 3,9 & 7,1 \\
\hline - drugo & 0,8 & & 0,7 & 1,0 & 0,3 \\
\hline Skupaj & 100 & 100 & 100 & 100 & 100 \\
\hline \multicolumn{6}{|l|}{ Sredstva za pridobitev stanovanja* } \\
\hline - lastna sredstva & 70,7 & 66,7 & 62,6 & 56,1 & 58,7 \\
\hline - finančna pomoč sorodnikov & 13,0 & 22,2 & 26,5 & 21,7 & 17,9 \\
\hline - zemljišče ali objekt od sorodnikov & 1,6 & 2,2 & 4,1 & 0,9 & 2,8 \\
\hline - posojilo nekdanjih delovnih org. & 23,4 & 20,0 & 8,5 & 16,3 & 15,8 \\
\hline - posojilo stan. sklada & 1,6 & 17,8 & 12,7 & 5,9 & 5,4 \\
\hline - posojilo iz NSVS & 2,4 & 4,3 & 0,7 & 1,9 & 1,2 \\
\hline - drugo posojilo pri banki & 17,1 & 26,1 & 27,4 & 19,8 & 23,8 \\
\hline
\end{tabular}

* Deleži v tabeli so med vsemi v skupini. (Med tistimi, ki sredstev niso uporabili, so torej tudi uporabniki, najemniki in lastniki, ki so stanovanje dobili z dedovanjem oz. kot darilo.)

Vir: Stanovanjska anketa 2005, FDV IDV, CDB 
Preglednica 11: Koliko sredstev hkrati so uporabile ranljive skupine?

\begin{tabular}{|c|c|c|c|c|c|}
\hline $\begin{array}{c}\text { Število sredstev } \\
\text { za pridobitev } \\
\text { stanovanja }\end{array}$ & $\begin{array}{c}\mathbf{6} 5 \text { in več let } \\
(\mathbf{n = 1 2 4}) \\
(\mathbf{\%})\end{array}$ & $\begin{array}{c}\text { Enostarševsko } \\
\text { gospodinjstvo } \\
(\mathbf{n = 4 5 )} \\
(\mathbf{\%})\end{array}$ & $\begin{array}{c}\text { Gospodinjstvo z } \\
\text { otroki (do 18 let) } \\
(\mathbf{n = 1 4 7 )} \\
(\%)\end{array}$ & $\begin{array}{c}\text { Revni } \\
(\mathbf{n = 1 0 7 )} \\
(\%)\end{array}$ & $\begin{array}{c}\text { Vsi Ljubljančani } \\
\text { (n=650) } \\
(\%)\end{array}$ \\
\hline $0^{*}$ & 27,4 & 30,4 & 35,9 & 42,6 & 39,0 \\
\hline 1 & 20,1 & 15,2 & 13,8 & 15,7 & 19,9 \\
\hline 2 & 24,3 & 28,3 & 31,7 & 24,1 & 24,1 \\
\hline 3 & 12,1 & 15,2 & 14,5 & 12,0 & 12,3 \\
\hline 4 & 4,0 & 10,9 & 2,8 & 3,7 & 4,1 \\
\hline 5 & 0,6 & & 1,4 & 1,9 & 0,6 \\
\hline 6 & & & & & 0,1 \\
\hline Skupaj & 100,0 & 100,0 & 100,0 & 100,0 & 100,0 \\
\hline
\end{tabular}

* Pomeni, da niso uporabili nobenega od zgoraj naštetih sredstev za stanovanje, so uporabniki ali najemniki, podnajemniki ali drugo, ali pa so do lastništva prišli z dedovanjem oz. so dobili stanovanje kot darilo.

Vir: Stanovanjska anketa 2005, FDV IDV, CDB

vanja (oz. gradnjo, prenovo). Pri tem prevladujejo posojila nekdanjih delovnih organizacij in bančna posojila. Starejša gospodinjstva so imela $v$ večji meri posojila nekdanjih delovnih organizacij, manj pogosto pa posojila pri banki, kot to velja za Ljubljano v celoti. To ni presenetljivo, saj so po vsej verjetnosti svoje stanovanje kupovali že pred časom, ko so bila posojila delovnih organizacij bolj pogosta in običajna. Tudi pri enostarševskih družinah so pogosta posojila delovnih organizacij ter bank, zelo pa izstopa tudi precejšen delež teh gospodinjstev, ki je imel posojilo stanovanjskega sklada. Pri družinah z otroki (do 18 let) med posojili izstopajo bančna posojila in posojila stanovanjskega sklada, medtem ko je med njimi precej manjši delež tistih, ki so imela posojilo nekdanjih delovnih organizacij. To je verjetno povezano s kasnejšim obdobjem nakupa stanovanja.

Kot je razvidno, gospodinjstva uporabljajo in združujejo različne vire za pridobitev stanovanja. V nadaljevanju predstavljamo, kolikšno število virov so uporabili anketiranci, ter primerjamo ranljive skupine z ljubljansko populacijo. Viri, ki jih opazujemo, so: lastna sredstva, finančna pomoč sorodnikov, zemljišče ali objekt od sorodnikov, posojilo nekdanjih delovnih organizacij, posojilo stanovanjskega sklada, posojilo iz NSVS, drugo posojilo pri banki. Poudarek je na gospodinjstvih, ki so v lastniškem stanovanju. Tako so gospodinjstva, ki niso uporabila nobenega vira za pridobitev stanovanja, definirana kot: uporabniki, ki živijo v stanovanju sorodnikov, najemniki, ali pa lastniki, ki so stanovanje dedovali ali dobili v dar.
Dobra tretjina gospodinjstev v Ljubljani je uporabila enega ali dva vira za pridobitev stanovanja. Zelo majhen delež pa je uporabil štiri ali več različnih virov. Izjema so enostarševske družine, kjer je kar desetina gospodinjstev združila štiri različne vire. Pri ranljivih skupinah je torej pogosteje potrebna kombinacija več virov za dosego stanovanja. Zato je za slednje nujno omogočiti čim več različnih virov, ki se lahko med seboj dopolnjujejo.

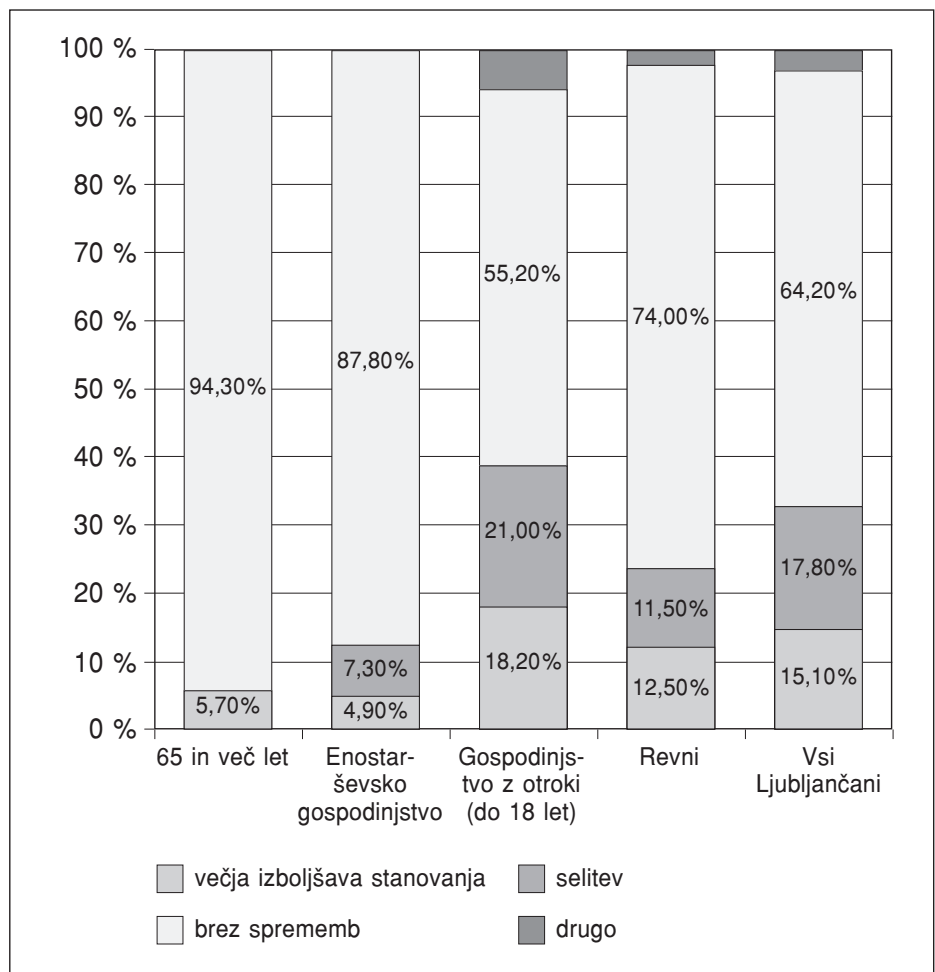

Slika 1: Prihodnje stanovanjske strategije ranljivih skupin v Ljubljani (Vir: Stanovanjska anketa 2005, FDV IDV, CDB) 
Iz preteklih strategij lahko predpostavljamo tudi prihodnje strategije gospodinjstev v primeru, da se situacija ne bo temeljno spremenila in bi bili na voljo novi viri (npr. prek ukrepov države ali mestne politike). V nadaljevanju bomo analizirali prihodnje stanovanjske strategije ranljivih skupin, saj nam slednje povedo, koliko med njimi ima namen spremeniti svoj stanovanjski položaj in na kakšen način. Pri tem je pomembno opozoriti na ugotovitve Mandičeve (2006), da so selivci v Sloveniji v glavnem premožnejši in selitev deluje kot sredstvo izboljšanja že tako dobrega položaja, le v manjši meri pa izboljšanje neprimernega stanovanjskega položaja gospodinjstva.

Delež selivcev je največji med gospodinjstvi z otroki (do 18 let) in je nekoliko višji kot v
Ljubljani. Pri vseh ostalih ranljivih skupinah so selivci podreprezentirani, kar se sklada s predhodnimi ugotovitvami o premožnejšem statusu selivcev. Večja izboljšava stanovanja je v Ljubljani skoraj tako pogosta strategija kot selitev. Vendar pa je delež tistih, ki bodo izboljšali obstoječe stanovanje podreprezentiran $\mathrm{v}$ vseh ranljivih skupinah, $\mathrm{z}$ izjemo gospodinjstev $\mathrm{z}$ otroki, kjer je rahlo nadreprezentiran.

Ker med selivci ni nobenega starejšega, te skupine nismo vključili v analizo glede prihodnjih strategij selitve in virov gospodinjstev.

V primeru selitev tako v Ljubljani kot med ranljivimi skupinami prevladuje kot »ciljni« lastniški status. Pri strategijah prevladuje

Preglednica 12: Prihodnji status in viri ranljivih gospodinjstev v Ljubljani

\begin{tabular}{|c|c|c|c|c|}
\hline & $\begin{array}{c}\text { Enostarševsko } \\
\text { gospodinjstvo } \\
(n=45) \\
(\%)\end{array}$ & $\begin{array}{l}\text { Gospodinjstvo z } \\
\text { otroki (do } 18 \text { let) } \\
\text { ( }=147) \\
(\%)\end{array}$ & $\begin{array}{c}\text { Revni } \\
(\mathrm{n}=107) \\
(\%)\end{array}$ & $\begin{array}{l}\text { Vsi Ljubljančani } \\
\begin{array}{c}(\mathrm{n}=650) \\
(\%)\end{array}\end{array}$ \\
\hline \multicolumn{5}{|l|}{ Prihodnji status gospodinjstva } \\
\hline - lastnik & 7,3 & 18,9 & 16,0 & 14,2 \\
\hline - najemnik v neprofitnem & & 0,7 & 2 & 0,2 \\
\hline - najemnik v profitnem/službenem stanovanju & & 1,4 & 1,9 & 2 \\
\hline - uporabnik & & & $1,9 \%$ & 0,4 \\
\hline - ne bo selil & 92,7 & 79,0 & 87,7 & 83,2 \\
\hline Skupaj & 100 & 100 & 100 & 100 \\
\hline \multicolumn{5}{|l|}{ Strategija } \\
\hline - ne bo selil (oz. ne bo lastnik) & 92,7 & 82,9 & 92,4 & 86,2 \\
\hline - bo kupil & 7,3 & 15,7 & 3,8 & 11,5 \\
\hline - bo dedoval, darilo & & 0,7 & 1,9 & 1,2 \\
\hline - bo gradil (novogradnja) & & 0,7 & 1,9 & 1,1 \\
\hline \multicolumn{5}{|l|}{ - bo dogradil, nadgradil } \\
\hline Skupaj & 100,0 & 100,0 & 100,0 & 100,0 \\
\hline \multicolumn{5}{|l|}{ Kraj selitve } \\
\hline - selitev znotraj istega mesta* & 7,3 & 12,8 & 6,7 & 8,4 \\
\hline - selitev v večje ali manjše mesto & & 4,3 & & 4,2 \\
\hline - selitev na podeželje & & $0,7 \%$ & & 0,7 \\
\hline - ni selitve & 92,7 & 82,3 & 93,3 & 86,7 \\
\hline Skupaj & 100,0 & 100,0 & 100,0 & 100,0 \\
\hline \multicolumn{5}{|l|}{ Financne strategije } \\
\hline - lastna sredstva & 7,3 & 15,0 & 5,8 & 11,1 \\
\hline - finančna pomoč sorodnikov & 0,0 & 3,6 & 1,0 & 4,3 \\
\hline - posojilo & 7,1 & 15,8 & 4,8 & 10,8 \\
\hline - zemljišče ali objekt od sorodnikov & 0,0 & 0,8 & 0,0 & 0,3 \\
\hline
\end{tabular}

* Vključuje tudi tiste, ki se bodo selili s pomočjo dograditve, nadgraditve.Vir: Stanovanjska anketa 2005, FDV IDV, CDB

Vir: Stanovanjska anketa 2005, FDV IDV, CDB 
nakup stanovanja, ki je nadreprezentiran med gospodinjstvi z otroki (do 18 let). Zanimivo, med revnimi je rahlo nadreprezentirana strategija novogradnja. Večina selivcev bo tudi ostala v Ljubljani, kar velja tudi za posamezne ranljive skupine. Kot $\mathrm{v}$ preteklih strategijah za nakup stanovanja tudi med prihodnjimi viri prevladujejo lastna sredstva.

\section{Sklepi}

Analizirali smo položaj 4 ranljivih skupin: enostarševskih gospodinjstev, revnih, družin z otroki do 18 let in gospodinjstev s članom, starim 65 ali več let. Med njimi in v primerjavi s celotnim prebivalstvom smo našli več razlik. Po naših podatkih prebivajo enostarševska gospodinjstva in revni pogosteje od drugih v najstarejših stanovanjih (zgrajenih pred letom 1914) ter $\mathrm{v}$ tistih, zgrajenih $\mathrm{v}$ zadnjih dveh desetletjih socializma, ki se tako izkazuje zanje kot dokaj razumevajoč. Glede fizičnih pomanjkljivosti stanovanja vidno izstopajo enostarševska gospodinjstva in revni, ki imajo izrazito več kot drugi prav vseh težav: pomanjkanja prostora in svetlobe, vlago, pomanjkljive napeljave. Ti dve skupini tudi bistveno pogosteje od drugih izražata negotovost glede stanovanja in pomanjkanja zasebnosti, pač spremljevalca profitnih stanovanj. Sintetičen kazalec stanovanjskih razmer, ki upošteva več dimenzij, kaže, da med revnimi gospodinjstvi in enostarševskimi gospodinjstvi nima primernih stanovanjskih razmer približno polovica gospodinjstev, med družinami $\mathrm{z}$ otroki sicer manj, a še vedno blizu $40 \%$, med starejšimi pa blizu 20 \%. Vse to kaže na znatne potrebe po izboljševanju stanovanjskih razmer ranljivih skupin in še zlasti na izpostavljenost enostarševskih gospodinjstev.

Glede dostopnosti različnih tipov stanovanjske oskrbe ranljivim skupinam se je pokazalo naslednje. Prav med vsemi ranljivimi skupinami, tako kot tudi v celotni populaciji, prevladuje bivanje $\mathrm{v}$ lastniškem stanovanju, kar nedvomno govori o potrebi po specifičnih inštrumentih podpore ranljivim skupinam tudi v lastniškem stanovanju, zlasti pri vzdrževanju in prenovi, pa tudi pri obratovalnih stroških.

Za enostarševska gospodinjstva je značilno, da znatno pogosteje od drugih živijo v neprofitnih stanovanjih, kar potrjuje njihovo socialno funkcijo v mestu. Veliko enostarševskih gospodinjstev prebiva tudi $\mathrm{v}$ tržnih najemnih stanovanjih, kar opozarja na problem kakovosti in cenovne dosegljivosti tržnih najemnih stanovanj in pomanjkanje neprofitnih stanovanj. Ta potreba se še bolj izrazito kaže ob skupini ravnih gospodinjstev. Za revna gospodinjstva $\mathrm{v}$ Ljubljani je namreč značilno, da bistveno redkeje od drugih prebivajo v cenovno ugodnejših opcijah (neprofitno stanovanje in kot uporabnik, ki ne plačuje najemnine), veliko pogosteje od drugih pa v tržnih stanovanjih. To opozarja na nevarnost razraščanja nekakovostnih in poceni najemnih stanovanj (pojav »oddajanja podrtij« oz. »Wreck-renting«) in potrebo po nadzoru nad kakovostjo tega sektorja; seveda pa to kaže tudi na nedostopnost neprofitnih oz. socialnih stanovanj skupini, ki bi jih zelo potrebovala.

Enostarševska gospodinjstva - in le nekaj manj od njih revni - v središču mesta bivajo pogosteje od ostalih prebivalcev Ljubljane; starejši so pogosteje od vseh ostalih locirani na obrobju; v druge mestne četrti pa se prav vse ranljive skupine naseljujejo redkeje kot ostalo prebivalstvo Ljubljane. Ti podatki opozarjajo na nevarnost večje koncentracije stanovanj slabše kakovosti $v$ središču mesta in s tem vzporedno tudi bolj ranljivega in manj vitalnega dela prebivalstva. Ta nevarnost tudi opozarja na potrebo po prenovi stanovanj in izboljšanju stanovanjskega okolja v središču mesta.

Ranljiva gospodinjstva so izrazito finančno obremenjena s stanovanjskimi stroški, pogosto pa dodatno še s posojili. Stanovanjski stroški predstavljajo dobri tretjini starejših gospodinjstev, revnih in enostarševskih družin več kot 30 \% dohodkov. Še posebej so pri tem izpostavljeni revni, saj med njimi skoraj dvema tretjinama gospodinjstev stanovanjski stroški predstavljajo več kot $30 \%$ dohodkov, kar se pogosto navaja kot meja sprejemljivosti obremenitve dohodka s stanovanjskimi stroški. Za vsa ta gospodinjstva bi torej lahko rekli, da živijo v neprimernem stanovanju. Nujna je torej pomoč pri plačevanju stanovanjskih stroškov revnim, ki bi dobila obliko redne podpore in bi bila širše dostopna tudi revnim lastnikom stanovanj.

Hkrati se ranljiva gospodinjstva redkeje selijo, kar kaže na njihovo manjšo zmožnost izboljšanja stanovanjskega položaja. Pogosto pri 
selitvi potrebujejo kombinacijo različnih virov. Analiza njihovih preteklih strategij za pridobitev stanovanja je pokazala na velik trud in angažiranost ranljivih skupin in tudi njihovega sorodstva pri zagotavljanju dostopa do sedanjega stanovanja, ki je kljub temu, kot smo videli, skoraj $\mathrm{v}$ polovici primerov neprimernega stanovanjskega standarda. Zato je pomembno, da se za te skupine nameni čim več različnih pomoči, ki jih bodo skupine lahko kombinirale ter na ta način izboljšale svoj stanovanjski položaj.

Selitev in večja izboljšava sedanjega stanovanja se kažeta kot medsebojno enakovredno zastopani strategiji v celotni populaciji in tudi med ranljivimi (razen med starejšimi, kjer je selitev praktično odsotna). To kaže na velik pomen prenove stanovanj kot mehanizma za izboljševanje stanovanjskih razmer ranljivega prebivalstva ter na potrebo po oblikovanju specifičnih inštrumentov stanovanjske politike, ki bodo lahko podprli ranljive skupine pri vključevanju $\mathrm{v}$ prenovo.

asist. dr. Maša Filipovič, Fakulteta za družbene vede, Univerza v Ljubljani

E-pošta: masa.filipovic@fdv.uni-lj.si

doc. dr. Srna Mandič, znanstvena svetnica, Fakulteta za družbene vede, Univerza v Ljubljani

E-pošta: srna.mandic@fdv.uni-lj.si

\section{Opomba}

[1] Kot revna gospodinjstva so bila definirana tista, ki imajo manj kot $60 \%$ mediane ekvivalentnega dohodka (kar za mesto Ljubljana na podlagi teh podatkov znaša 97.500 sit).

\section{Literatura in viri}

Avramov, D. (1995) Homelessness in the European union: Social and legač context of housing exclusion in the 1990s. Feantsa, Brussels.

Boškič, R., Filipovič, M. (2002) Ranljivost na stanovanjskem področju - kako jo zaznavajo organizacije in oblikovalci politik v Sloveniji. V: Mandič, S. (ur.), Filipović, M. (ur.). Stanovanjske študije, Ljubljana: Fakulteta za družbene vede, 2002, str. 71-91

Dolenc, D. (2003). Migracije z območja nekdanje Jugoslavije $v$ Slovenijo in njihovi socio-geografski učinki. Magistrska anloga. Ljubljana: Filozofska fakulteta.

Duffy, K. (1998) Opportunity and risk: Trends of social exclusion in Europe. Council of Europe, Project on Human dignity and social exclusion.

Edgar, B., Doherty, J., Meert, H. (2002) Access to Housing: Homelessness and Vulnerability in Europe. Policy press, Bristol.

Edgar, B., Meert, H., Doherty, J. (2004) Third Review of Statistics on Homelessness in Europe. Developing an Operational Definition of Homelessness. Feantsa, Brussels.

Flaker, V. (1999Stanovanjske težave ljudi z dolgotrajnimi duševnimi stiskami in možne rešitve. V: Mandič, $S$. (ur.). Pravica do stanovanja : brezdomstvo in druga stanovanjska tveganja ranljivih skupin. Visoka šola za socialno delo, Ljubljana.

Leskošek, V. (1999). Stanovanjse kot pomemben prispevek k samostojnosti mladih. V: Mandič, S. (ur.). Pravica do stanovanja : brezdomstvo in druga stanovanjska tveganja ranljivih skupin. Visoka šola za socialno delo, Ljubljana.

Mandič (2006): Stanovanjske strategije. V Mandič S., Cirman, A. (ur.) Stanovanje v Sloveniji 2005. FDV, Ljubljana.

Mandič, S. (1999). Stanovanjska tveganja, ranljive skupine in novi pogledi : uvod. V: Mandič, S. (ur.). Pravica do stanovanja : brezdomstvo in druga stanovanjska tveganja ranljivih skupin. Visoka šola za socialno delo, Ljubljana.

Mandič, S., Filipovič, M. (2005): Stanovanjski primanjkljaj v Sloveniji: problem, ki ga ni?. Teor. praksa, jul./dec. letn. 42, št. 4/6, str. 704-718.

Nacionalni stanovanjski program (NSP), 2000, Uradni list RS, št. 43/2000. www.uradni-list.si (18.11.2006)

Razpotnik, Š., Dekleva, B. (2005), Kralji ulice - prehodno poročilo o poteku akcijske raziskave. Socialna pedagogika, 9, 3: 265-300.

Stanovanjski program Mestne občine Ljubljana za leto 2007. Javni stanovanjski sklad Mestne občine Ljubljana. Ljubljana, januar 2007.

Zaviršek, D.. (1999). Ranljivost žensk na področju stanovanja. V: Mandič, S. (ur.). Pravica do stanovanja brezdomstvo in druga stanovanjska tveganja ranljivih skupin. Visoka šola za socialno delo, Ljubljana. 